\title{
Satire in the Komnenian Period: Poetry, Satirical Strands, and Intellectual Antagonism
}

\author{
Nikos Zagklas
}

The Byzantines had an exceptional skill for praising and flattering their patrons or fellow intellectuals, but they had also an extraordinary talent to poke fun at their rivals and even destroy their reputation. Praise and criticism, though diametrically opposed to each other, were equally essential tools by many Byzantine literati competing for financial and social promotion. If we narrow the picture to the expression of criticism and disapproval, satire and invective were the two primary types of texts that gave a tangible form to it. ${ }^{1}$ Next to various kinds of writings in prose-ranging from satires in Lucianic manner to abusive invectives and parodies-we find several works in verse. ${ }^{2}$ Indeed, verse (and in particular the iambic one) ${ }^{3}$ was a very apt medium for the articulation of satiric and humorous treatment of human faults and foibles throughout the Byzantine times. To put it in Floris Bernard's words: "Satirical poetry is a constant feature in Byzantium."4

The 12th century is no exception to this rule. During this period, the intellectual environment in Constantinople becomes even more competitive and aggressive for many authors. In order to acquire more commissions and eventually move to higher echelons in their career, many of them had to project themselves as matchless rhetors, while on various occasions they did not hesitate to even attack rivals that would question their intellectual authority. This sociocultural development triggered an exponential increase in the

1 It must, though, be stressed that satire and invective are genres with fuzzy edges, so it is not easy to draw a clear line between them (Przemysław Marciniak, "The Art of Abuse: Satire and Invective in Byzantine Literature, a Preliminary Survey," Eos 103 (2016): 350).

2 For recent discussions of verse satires and invectives, see Floris Bernard, Reading and Writing Byzantine Secular Poetry, 1025-1081 (Oxford, 2014), 266-99; Marc D. Lauxtermann, Byzantine Poetry from Pisides to Geometres. Texts and Contexts. Volume Two (Vienna, 2019), 119-44 (with comprehensive bibliography).

3 The iambikè idea was central in late antiquity and Byzantium (Gianfranco Agosti, "Late Antique Iambics and the Iambikè Idea," in Iambic ideas. Essays on a Poetic Tradition from Archaic Greece to the Late Roman Empire, ed. Alberto Cavarzere et al. (Lanham, MD, 2001), 219-55; Bernard, Poetry, 61 and 340).

4 Bernard, Poetry, 267. 
production of verse satirical writings. ${ }^{5}$ Although many of them are associated with intellectual antagonism, ${ }^{6}$ there are also works for various other occasions: for example, Theophylact of Ochrid reprimands a priest that criticized other clerics; ${ }^{7}$ Manganeios Prodromos ridicules an old man for taking a young woman as his wife; ${ }^{8}$ Theodore Balsamon derides a little eunuch who intends to embark on the learning of schedography; ${ }^{9}$ and Efthymios Tornikes castigates an anonymous bishop of Seleucia who seized the bishopric of Euboea, while he is also the author of a humoristic piece over the dispute of the people of Thebes and Euboea for the pronunciation of "nu" and "lambda."10 What is more, this continuous production of satirical discourse, from the late nth century down to the early 13th century, goes hand in hand with a number of innovative shifts and new trends; for example, it is in the mid-12th century that satirical works take for the very first time the form of dramas, mainly thanks to Prodromos' Katomyomachia that constitutes a Byzantine version of mock epic that builds upon Batrachomyomachia, ${ }^{11}$ and Haplucheir's iambic Dramation, which is yet another Komnenian work satirizing the futility of letters. ${ }^{12}$ It is

$5 \quad$ And poetry more broadly; on this issue, see Elizabeth Jeffreys, "Why Produce Verse in Twelfth-Century Constantinople?," in "Doux remède ..." Poésie et poétique à Byzance, ed. Paolo Odorico, Panagiotis A. Agapitos, and M. Hinterberger (Paris, 20o9), 219-28; Nikos Zagklas, "How Many Verses Shall I Write and Say?': Writing Poetry in the Komnenian Period," in A Companion to Byzantine Poetry, ed. Wolfram Hörandner, Andreas Rhoby, and Nikos Zagklas (Leiden, 2019), 237-263.

6 For some works linked to intellectual antagonism, see the second section of the chapter.

7 Theophylact of Ochrid, Poems, ed. Paul Gautier, Théophylacte d'Achrida Discours, Traités, Poésies, vol. 2 (Thessalonike, 1980), 9.361-65.

8 Manganeios Prodromos, Unedited Poems, ed. Emmanuel Miller, "Poésies inédites de Théodore Prodrome," Annuaire de l'Association pour l'encouragement des études greques en France 17 (1883): 18-64.

9 Theodore Balsamon, Poem 41, ed. Konstantin Horna, "Die Epigramme des Theodoros Balsamon," Wiener Studien 25 (1903): 165-217; on this poem, see Andreas Rhoby, "The Epigrams of Theodore Balsamon: Their Form and Their Function," in Middle and Late Byzantine Poetry: Texts and Contexts, ed. Andreas Rhoby and Nikos Zagklas (Turnhout, 2018), 39-40.

10 Efthymios Tornikes, Poems, ed. Wolfram Hörandner, "Dichtungen des Euthymios Tornikes in Cod. gr. 508 der Rumänischen Akademie," in Wolfram Hörandner. Facettes de la littérature byzantine. Contributions choisies, ed. Paolo Odorico, Andreas Rhoby, and Elizabeth Schiffer (Paris, 2017), 104-12 and 127-31.

11 Theodore Prodromos, Katomyomachia, ed. Herbert Hunger, Der byzantinische Katz-Mäuse-Krieg. Theodore Prodromus, Katomyomachia (Graz, 1968); for a recent study of the text, see Przemysław Marciniak and Katarzyna Warcaba, "Theodore Prodromos' Katomyomachia as a Byzantine Version of Mock-Epic," in Middle and Late Byzantine Poetry, 97-110.

12 Michael Haplucheir, Dramation, ed. Pietro Luigi M. Leone, "Michaelis Hapluchiris versus cum excerptis," Byzantion 39 (1969): 251-83; for a very interesting interpretation of the 
also around the same period that verse satires make their first appearance in the vernacular, with the composition of the four Ptochoprodromic poems. ${ }^{13}$

However, this study does not aim to focus on the rise of these novel types of Byzantine satirical discourse. It will rather discuss some learned verse satires and invectives to advance our understanding of some 12th-century trends and tendencies. Since the material is vast, it will focus on texts written in the mid-12th century, when the antagonism between Komnenian poets was in its heyday. In the first part, there will be a discussion of the models some poets used for the composition of their works, while in the second the focus will shift to the sociocultural reasons behind the writing of these works and the art of mocking and castigating between some contemporary authors in a few contexts.

\section{Models: The Lucianic Tradition and the Hellenistic Mock Epigram}

In 2005 Roderich Reinsch published an anonymous poem in 44 political verses, which he claimed that he found on a single surviving folio of a parchment manuscript owned by a private collector. ${ }^{14}$ The poem recounts the story of an individual in poor health, whose soul is violently snatched away by demons of the underworld. But once the soul of the unfortunate man is brought to Hades, the demons face an unexpected challenge. The underworld abounds with such a high number of courts that they are not able to decide which one was the right one to conduct a forensic inspection of his soul and reach a verdict about his fate. After having been dragged through various courts, he is finally brought before king Minos, the ultimate judge in the underworld, who determines that his soul should be sent back to his body: ${ }^{15}$

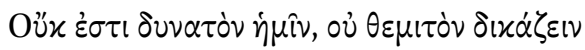

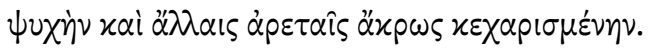

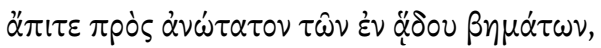

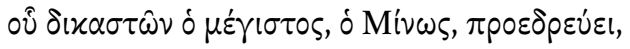

work, see Przemysław Marciniak, "The Dramation by Michael Haplucheir: A Reappraisal," Symbolae Osloenses 94 (2020), 1-18.

13 For these four texts, see Chapter 15 in the present volume.

14 Roderick Diether Reinsch, "Indizien einer Zuständigkeitsregelung für byzantinische Gerichte des 12. Jhs.," in Summa, Dieter Simon zum 7o. Geburtstag, ed. Rainer M. Kiesow and Regina Ogorek (Frankfurt/M., 2005), 505-09.

15 Reinsch, "Indizien einer Zuständigkeitsregelung für byzantinische Gerichte des 12. Jhs.," 506 . 


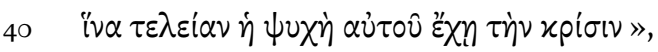

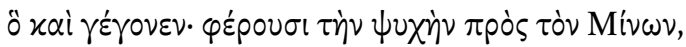

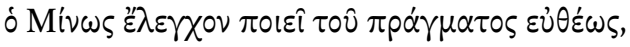

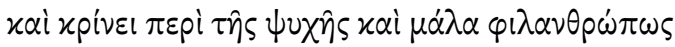

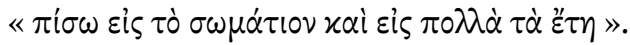

It is not possible for us, nor legitimate, to judge the soul fully granted with many other virtues. Go to the most superior court in Hades, where Minos, the greatest of the judges, acts as chair, [40] in order for the soul to finally receive a verdict. This was done; they brought the soul in front of Minos; Minos immediately examines the situation, and quite generously decides about the fate of the soul: "Go back to your body and live many years."

At the very outset of his analysis Reinsch describes the poem as a literary katabasis in a Lucianic manner and for this reason argued for a 12th-century dating: ${ }^{16}$

Das Gedicht reiht sich ein in die literarische Tradition der Unterweltsfahrten und weist-beide in der Tradition Lukians-eine enge Verwandtschaft zum ebenfalls im 12. Jahrhundert entstandenen Dialog Timarion auf.

At one point, Reinsch even notes that the text was most likely written by a peer of Theodore Prodromos, Constantine Manasses, or John Tzetzes. Although when compared with Byzantine works, the work is not void of literary value and humor, it is a crafty literary hoax by Reinsch, demonstrating that not only Byzantines, but also Byzantinists know how to be playful and display a good sense of humor. More important for our purposes, though, is that Reinsch's made-up poem exemplifies in the most precise way our modern view about the character of Byzantine satire after the 11th century. We tend to think that the 12th century signifies a shift in the nature of Byzantine satirical writing due to the emergence of works that resemble the Lucianic satirical dialogues. It is true that from the end of the 11th century onward quite a few authors set their pens to write satires in the style of Lucian. One of the earliest examples is the

16 Reinsch, "Indizien einer Zuständigkeitsregelung für byzantinische Gerichte des 12. Jhs.," $5^{\circ}$. For a general introduction to katabasis in Byzantine texts, see Stelios Lambakis, $O \iota$

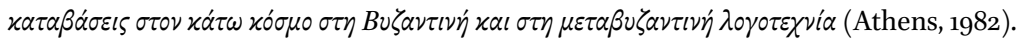


anonymous satire of Timarion. ${ }^{17}$ As Ingela Nilsson has noted, the anonymous author draws his inspiration, among other models, from "the Lucianic satirical dialogue, especially the ones set in Hades, the Dialogues with the Dead"; and "the fantastic travel tale, parodied by Lucian in his True Histories."18

In addition to the Timarion, most likely a work of the early 12th century, there is a group of seven works, all by Theodore Prodromos, which, according to many modern scholars, owe much to Lucian's satirical dialogues. ${ }^{19}$ This group consists of Sale of Political and Poetical Lives, The Ignorant, or the Grammarian in his own eyes, The Executioner, or the Doctor, Amarantos, or the Passions of the Old Man, Plato-lover, or Leatherworker, Against a Lustful old Woman, Against a Man with a Long Beard. ${ }^{20}$ However, of special interest for our purposes are the last two works, since they are the only ones written exclusively in verse. ${ }^{21}$ The question I want to address in the remainder of this section is whether these two poems by Prodromos can be considered as "Lucianic" as his five prose satires. I want to look at their models and argue that when it comes to verse satire

17 There is also the case of the Philopatris, which can also be a product of the 11th or even the 1oth century; see Rosario Anastasi, "Tradizione e innovazione nella satira bizantina: le satire pseudolucianee," Atti della Academia Peloritana dei Pericolanti, Classe di Lettere, Filosofia e Belle Arti, 66 (1990): 57-73.

18 See Ingela Nilsson, "Poets and Teachers in the Underworld: From the Lucianic Katabasis to the Timarion," Symbolae Osloenses Norwegian Journal of Greek and Latin Studies 9o.1 (2016): 183. For other recent studies dealing with Timarion from another point of view, see Anthony Kaldellis, "The Timarion: Toward a Literary Interpretation," in La face cachée de la littérature byzantine: le texte en tant que message immédiat, ed. Paolo Odorico (Paris, 2012), 275-87; Dimitris Krallis, "Harmless Satire, Stinging Critique: Notes and Suggestions for Reading the Timarion," in Power and Subversion in Byzantium, ed. D. Angelov and M. Saxby (Surrey, UK, 2013), 221-45; Byron MacDougall, "The Festival of Saint Demetrios, the Timarion, and the Aithiopika," Byzantine and Modern Greek Studies 40.1 (2016):135-50.

19 See Przemysław Marciniak, "Reinventing Lucian in Byzantium," Dumbarton Oaks Papers 70 (2017): 209-24.

20 All these works have been edited in Theodore Prodromos, Satires, ed. Tommaso Migliorini, "Gli scritti satirici in greco letterario di Teodoro Prodromo: introduzione, edizione, traduzione e commenti," PhD diss. (Pisa, 2010); for the texts of Bion Prasis and Amarantos, see also Eric Cullhed in Przemysław Marciniak, Taniec w roli Tersytesa: Studia nad satyra bizantyńska [A dance in the role of Thersites: studies on Byzantine satire] (Katowice, 2016), 185-203; Tommaso Migliorini, "Teodoro Prodromo, Amaranto," Medioevo Greco 7 (2007): 183-247; for an analysis of the last text, see Eric Cullhed, "Theodore Prodromos in the Garden of Epicurus: The Amarantos," in Dialogues and Debates from Late Antiquity to Late Byzantium, ed. Averil Cameron and Niels Gaul (London, 2017), 153-66.

21 His satires Sale of Political and Poetical Lives and Amarantos, or the Passions of the Old Man are a mixture of prose and verse; see Nikos Zagklas, "Experimenting with Prose and Verse in Twelfth-Century Byzantium: A Preliminary Study," Dumbarton Oaks Papers 71 (2017): $229-48$. 
Prodromos and other Komnenian authors tend to adhere to a different satiric tradition.

Let us begin with the poem Against a Lustful Old Woman, a quite long poem of 102 iambics that vehemently attacks an old woman. At the very beginning of the text we are told that she is the world's ugliest woman and even older than Thoukritos, a fictional Lucianic hero and primary example of old age; immediately after she is verbally castigated and called various names: e.g. she is lustful and wicked; she is filthy and is likened to a swamp filled with eels and frogs; she is a disgrace and shame to human nature. It is impossible to conceal her real age, even if she uses makeup on her face and deep-colored dyes on her hair:22

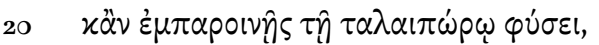

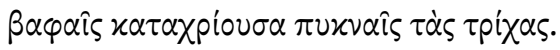

O old woman, even your eyelashes are grey-haired, [20] even if you act offensively against the wretched nature by anointing your hair with bold dyes.

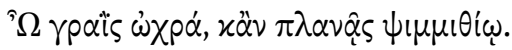

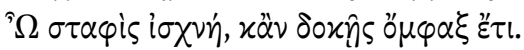

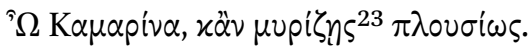

O pale old woman, even if you are deceitful with your white pigment powder! O dried raisin, even if you seem an unripe grape! O Kamarina, ${ }^{24}$ even if you are abundantly anointed.

Unlike her countenance, which is in the worst possible state, her erotic longing is in its heyday; she acts as a promiscuous prostitute in search of a young husband. But she is obviously a fool if she thinks that young men will respond to her erotic longing: 25

22 Against a Lustful Old Woman in Theodore Prodromos, Satires, p. 3, vv. 19-21 and 26-28.

23 Migliorini's edition reads $\mu \nu p i \zeta_{n}$, but I prefer the reading offered by some manuscripts; $\mathrm{cf}$. the apparatus criticus on p. 5 .

24 The old woman is not compared to the City of Kamarina in Sicily, but to the marshy and stinking lake Kamarina, which according to the tradition was drained by the Sicilians.

25 Against a Lustful Old Woman in Theodore Prodromos, Satires, p. 3, vv. 37-40 and p. 4, vv. $65^{-70}$. 


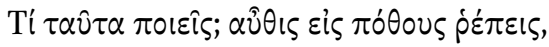

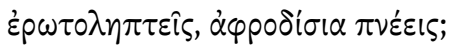

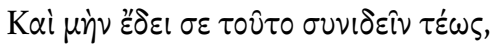

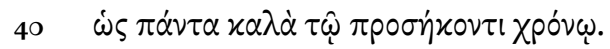

What are you doing here? You fall into desires again, you are captured by eros, you breathe out sexual scents? But you do not know the thing you by now ought, [40] that everything is good in its own time.

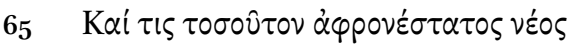

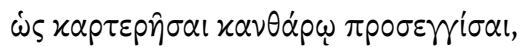

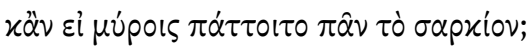

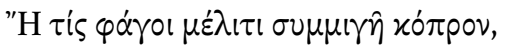

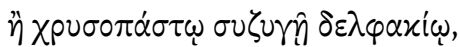

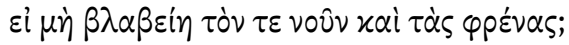

And which young man is so foolish to patiently bear the nearing to a dung beetle, ${ }^{26}$ even if the entire body is sprinkled with perfumes? Or who would eat honey mixed with dung, or match with a pig overlaid with gold, [70] unless his mind or spirit had been harmed?

The poet concludes his attack by saying that death befits better to this "lustful fraud" than a young husband: ${ }^{27}$

$\Phi \theta \dot{\alpha} p \eta \theta 1 x \alpha x \hat{\omega} \varsigma \tau \hat{\omega} \nu x \alpha x \hat{\omega} \nu \dot{\eta} x \alpha x i \omega \nu$,

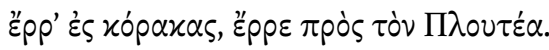

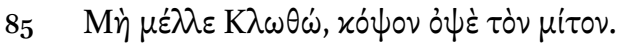

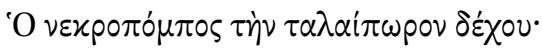

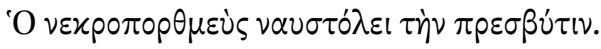

You may suffer a bad death, more wicked thing than the evil! Go to crows, go to Plutus! [85] You Clotho, do not linger to cut off the thread at once! You psychpomp, receive the poor thing! You ferryman of the dead, guide with your boat the old woman!

26 The motif of the dung beetle is very common in satirical writings that goes back to antiquit, see Emilie van Opstall, "The Pleasure of Mudslinging: An Invective Dialogue in Verse from 1oth-Century Byzantium," Byzantinische Zeitschrift 108 (2015): 708. Against a Lustful Old Woman in Theodore Prodromos, Satires, p. 4, vv. 83-87. 
In sum, it is clear that the old woman is condemned for her vulgar behavior throughout the poem: instead of being prudent and virtuous, she is an old whore. After her death, the ultimate judge in the underworld threw her corpse to Cerberus, but her skin, which is as hard as a shell, weakens even Cerberus' jaws ${ }^{28}$ — a joke that intends to add to the playfulness of the poem.

Both Enrico Magnelli and Przemysław Marciniak have noticed some Lucianic imagery throughout the text, such as the reference to Thukritos mentioned earlier. ${ }^{29}$ On top of that, the latter has argued that in this poem "Prodromos joins together two literary traditions, Aristophanic and Lucianic,"30 while in a more recent paper he notes that "the text, in fact an elaborate invective, uses literary imagery taken from Aristophanes, epigrammatic tradition and Lucian."31 But in my view, the ancient epigrammatic tradition plays a primary role in the generic formation of this text. The poem largely clings on the tradition of ancient scoptic epigrams mocking old women for their erotic desire. There are approximately 14 poems dealing with this topic in the eleventh book of the Greek Anthology. ${ }^{32}$ Take, for example, two epigrams ascribed to Nicarchus and Bassus of Smyrna that attack old women for their outrageous erotic desire. ${ }^{33}$

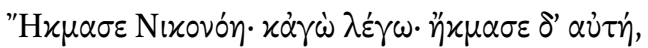

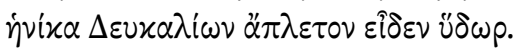

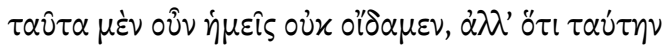

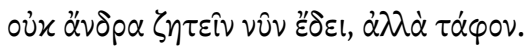

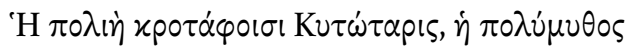

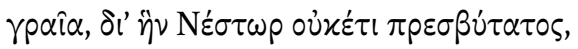
$\dot{\eta} \varphi \dot{\alpha} 0 \varsigma \dot{\alpha} \theta \rho \dot{\eta} \sigma \alpha \sigma^{\prime} \dot{\varepsilon} \lambda \alpha \dot{\alpha} \varphi 00 \pi \lambda \varepsilon \dot{\varepsilon}, \dot{\eta} \chi \varepsilon \rho i \lambda \alpha \alpha \hat{\eta}$

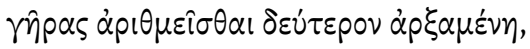

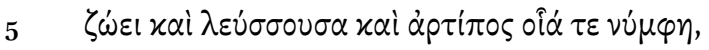

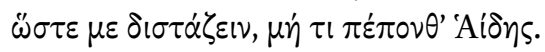

28 Against a Lustful Old Woman in Theodore Prodromos, Satires, p. 4, vv. 101-O2.

29 Enrico Magnelli, "Prodromea (con una nota su Gregorio di Nazianzo)," Medioevo Greco 10 (2010): 116-22; Przemysław Marciniak, "Prodromos, Aristophanes and a Lustful Woman. A Byzantine Satire by Theodore Prodromos," Byzantinoslavica 73 (2015): 23-34.

$30 \quad$ Marciniak, "Prodromos, Aristophanes and a Lustful Woman," 26.

31 Przemysław Marciniak, "It Is Not What It Appears to Be: A Note on Theodore Prodromos' against Old Woman," Eos 103 (2016): 110.

32 See Anthologia Graeca, Book 11, ed. Hermann Beckby, Anthologia Graeca, 4 vols. (Munich, $1957-58)$, nos. $65,66,67,68,69,71,72,73,74,119,256,374,408,409$. This has been noted briefly in Theodore Prodromos, Satires, p. 9.

33 Trans. in William Roger Paton, The Greek Anthology, 5 vols. (New York, 1925-27), vol. 4, p. 107. 
71

Niconoe was once in her prime, I admit that, but her prime was when Deucalion looked on the vast waters. Of those times we have no knowledge, but of her now we know that she should seek not a husband, but a tomb.

72

Cytotaris with her grey temples, the garrulous old woman who makes Nestor no longer the oldest of men, she who has looked on the light longer than a stag and has begun to reckon her second old age on her left hand, is alive and sharp-sighted and firm on her legs like a bride, so that I wonder if something has not befallen Death.

The spirit and the main idea of the two epigrams are very close to Prodromos' text: in all three of them the women are old (even older than Thoukritos, Deucalion, and Nestor, respectively); despite their old age and obnoxious appearance, they are after a young husband; instead of seeking a young husband, they should, however, look for a tomb for their almost decomposed carcass. But next to these similarities, there are some differences too. Whereas Prodromos' poem consists of 102 verses, the two epigrams are very short. Moreover, Prodromos' poem is more abusive due to the use of extensive name-calling; as the narrative of the text unfolds from the first to the last verse, there is an uninterrupted intensity of exaggeration paired with abusive attack.

A similar technique is followed in the poem Against a Man with a Long Beard, which has also been described as a work in Lucianic style, ${ }^{34}$ and in which Prodromos lampoons an old man that considers himself the ultimate source of knowledge because of his long and scruffy-looking beard. In the opening verses the poet concentrates on the long beard of the old man which stinks like a goat. It is so long and heavy that he stoops down. He is advised to cut it off to set his jaw free from this unbearable burden, otherwise the cynic Menippus with his axe will cut it off. He fools himself if he thinks that the long beard is a sign of his wisdom. If so, goats with long beards should be considered as paradigms of wise philosophers: ${ }^{35}$

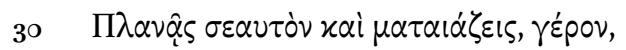

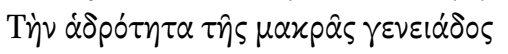

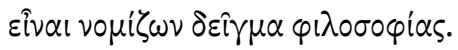

34 Janek Kucharski and Przemysław Marciniak, "The Beard and Its Philosopher: Theodore Prodromos on Philosopher's Beard in Byzantium," Byzantine and Modern Greek Studies 41.1 (2017): 45-54. 
You're foolishly deluding yourself, old man, taking the exuberance of your beard to be a mark of wisdom.

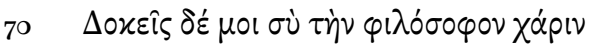

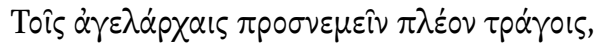

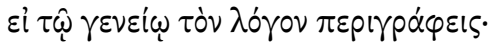

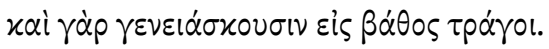

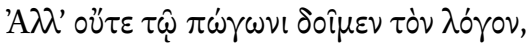

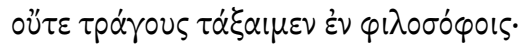

[70] You seem to me to assign philosopher's grace more to the flocks of goats, if you're defining reason by the beard: for it is goats that grow a long beard. But let us not give reason to the beard, nor rank the goats among philosophers.

But "Measure is the best of all things," Prodromos says, and for this reason he asks from the beard to grow even more and turn into a tool of punishment that will smash the back of the old and feeble man. ${ }^{36}$

As with the poem Against a Lustful Woman, this poem is filled with a good deal of Lucianic imagery. ${ }^{37}$ For instance, Prodromos makes use of some Lucianic heroes, such as Thukritos and the Cynic Menippus. He even includes an explicit mention of Lucian by calling him "sweet Syrian." ${ }^{38}$ But while Lucian ridicules bearded philosophers, here Prodromos derides an individual who thinks he is a philosopher because of his long beard. Even though he refers to Lucian and borrows some of his imagery, Prodromos' work is again closely linked to scoptic epigrams (just like the first poem). The eleventh book of the Greek Anthology includes at least five works treating the very same topic. ${ }^{39}$ A telling example is the epigram no. 430, which consists of a single elegiac distich. ${ }^{40}$

36 Against a Man with a Long Beard in Theodore Prodromos, Satires, p. 20, vv. 70-75.

37 Most of them have been noted in Kucharski and Marciniak, "Beard and Its Philosopher," $45^{-54}$.

38 For this reference, see also Chapter 2 in the present volume.

39 See Anthologia Graeca, Book 11, ed. Beckby, nos. 156, 157, 354, 410, 430.

40 Trans. in Paton, Greek Anthology, vol. 4, p. 277. The poem is also included in the collection of Greek proverbs put together by Aristoboulos Apostoles; see Ernst Ludwig von Leutsch, Corpus paroemiographorum Graecorum, 2 vols. (Göttingen, 1851; repr. Hildesheim, 1958), vol. 2, p. 39o, no. 93 e. 


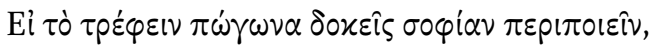

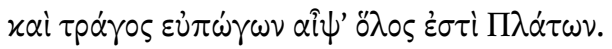

If you think that to grow a beard is to acquire wisdom, a goat with a fine beard is at once a complete Plato.

Just like in the case of the poem against the woman, the driving motivation behind the critic and the message between Prodromos' poem and the scoptic epigram is the same: they construct attacks against individuals who camouflage their lack of education and knowledge by growing a long beard, while in both of them they are compared to goats. But despite the close similarity between Prodromos' two poems and the mock epigrams from the Greek Anthology, one could claim that this is a random subject-matter resemblance: the mocking of an old woman who is driven by her erotic desire and an old man who considers himself a towering philosopher due to his long beard are probably not without parallels in other texts, be they classical or Byzantine.

And yet, there is more evidence suggesting that the mock epigram is the main paradigm for many verse satires in the Komnenian period. The most important one is that Prodromos was not the only 12th-century poet who appropriated the eleventh book of the Greek Anthology for the mocking of old age. If we take a look at his environment, his literary peer, student, and friend, Niketas Eugenianos, composed a group of 24 epigrams that are rewritings of various poems from the Greek Anthology ${ }^{41}$ Among these poems, there is a work mocking an old woman, which is a paraphrase of the poem no. 408 ascribed to Luccilius from the eleventh book of the Palatine Anthology:42

\section{(1) Greek Anthology}

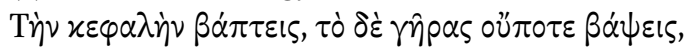

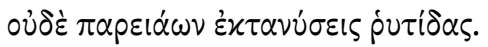

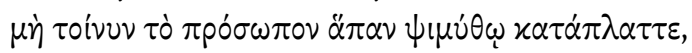

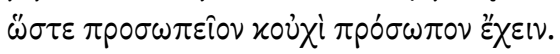

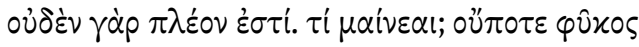

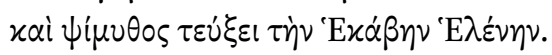

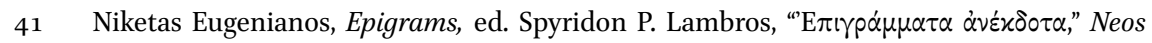
Ellenomnemon 11.4 (1914): 353-68-; for the similarities between these texts and epigrams

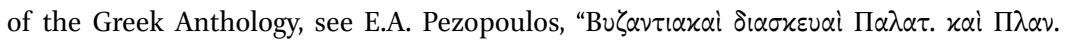

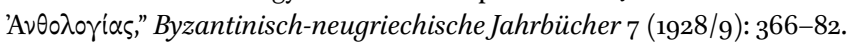

42 Greek Anthology, ed. Beckby, Book 11, no. 408 and On an Old Woman in Niketas Eugenianos, Epigrams, 357-58; the close resemblance has already been noted in Pezopoulos,

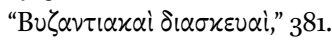


You dye your hair, but you will never conceal your old age, or smooth out the wrinkles of your cheeks. So don't plaster all your face with white lead, so that you have not a face, but a mask; for it serves no purpose. Why are you out of your wits? Rouge and paste will never turn Hecuba into Helen.

(2) Niketas Eugenianos

Eis rpaûv

Mì $\beta \dot{\alpha} \pi \tau \varepsilon \tau \dot{\alpha} \pi \rho \delta ́ \sigma \omega \pi \alpha \mu \eta \delta^{\prime} \dot{\alpha} \nu \alpha \chi p i ́ o v$,

$\mu \dot{\eta} \tau \dot{\eta} \nu x \varepsilon \varphi \alpha \lambda \dot{\eta} \nu x \alpha \grave{i} x \varepsilon \varphi \alpha \lambda \hat{\eta} \varsigma \tau \dot{\alpha} \varsigma \tau \hat{l}^{\prime} \chi \alpha \varsigma$.

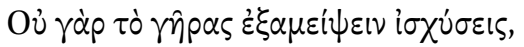

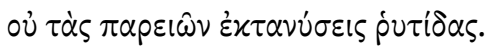

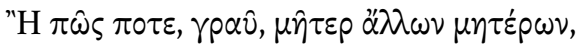

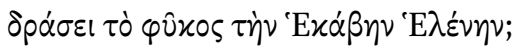

\section{On the old woman}

Don't make-up your face nor smear yourself with oil, don't [put powder] on your head and its hair. For you won't be able to conceal your old age or stretch tight the wrinkles on your cheeks. Or how will the rouge, old woman, mother of all the other mothers, turn Hecuba into Helen?

The resemblance is conspicuous and leaves no doubt that Eugenianos modeled his satiric poem on the epigram 408 from the Greek Anthology. In both epigrams, we are told that even the use of makeup does not help the woman to conceal her old age and turn her from Hecuba to Helen. ${ }^{43}$ The only difference between the two works is that the elegiac couplets of the model have been turned into iambic verses (I will return to this issue).

It is also important to note that works ridiculing individuals of old age are not the only examples of 12th-century verse satire that owe much to ancient mocking epigrams from the eleventh book of the Greek Anthology. For example, in the 14th-century manuscript Vaticanus gr. 743, there is a group of seven poems, which probably were written by an unknown poet in the 12th century.4 Three of them share many features of satirical writings: the first poem is a debunking of an astrologer who fails to foretell the future and all the sufferings he will undergo; the second poem tells the humorous story of a starving poor man accused by his neighbor that he misappropriated money on frivolous grounds;

43 There are even more poems from the Greek Anthology that are similar to Eugenianos' piece; see Greek Anthology, ed. Beckby, Book 11, nos. 66, 67, 68, 69, and esp. 37o.

44 Nikos Zagklas, "Astrology, Piety and Poverty: Seven Anonymous Poems in Vaticanus gr. 743," Byzantinische Zeitschrift 109.2 (2016): 895-918. 
the third poem, which bears the title On an Ape Who Married a Tall Woman pokes fun at a man of short size who can kiss only his wife's buttocks. Most interestingly, the first and the third poems are Byzantine rewritings of poems from the eleventh book of the Greek Anthology ${ }^{45}$ Here is a very good example:

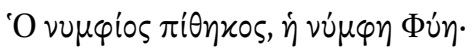

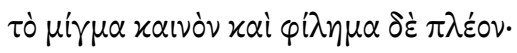

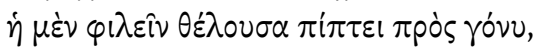

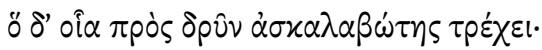

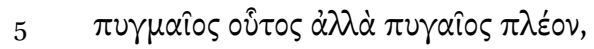

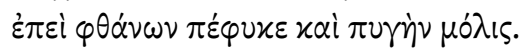

The bridegroom is an ape, the bride another Phye. It is a strange combination and their kisses are even stranger; when she wants to kiss him, she falls on her knees, and he runs like a lizard upon an oak tree. [5] He is a midget, or rather a lover of buttocks, since he can barely reach her bottom. ${ }^{46}$

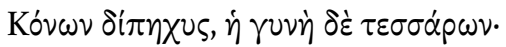

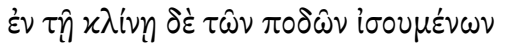

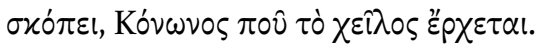

Conon is two cubits tall, his wife four. In bed, then, with their feet at the same level, reckon where Conon's lips are. ${ }^{47}$

Just like Prodromos and Eugenianos, the anonymous poet has reworked a theme that we come across in the eleventh book of Greek Anthology.

The list of Komnenian poems that draw their themes from the eleventh book of the Greek Anthology could possibly be further expanded, but I think by now it has become clear that many authors of this period exploit the ancient scoptic epigrammatic tradition to the utmost. The scornful mockery of lustful old women, old men who consider themselves wise, and short men married to tall wives are popular topics in the 12th-century poetry that we mainly encounter in the eleventh book of the Greek Anthology. But why is this finding so important? First of all, the Komnenian satirical poetry, unlike the contemporary

45 Zagklas, "Astrology, Piety and Poverty," 912-13.

46 Zagklas, "Astrology, Piety and Poverty," 905.

47 See Anthologia Graeca, Book 11, ed. Beckby, no. 108. Trans. in Paton, Greek Anthology, vol. 4, p. 6 or. 
prose satire, is not Lucianic to the degree we always tend to think, or, to put it better, Lucian's work is not the only model of these works. As a matter of fact, Reinsch' made-up verse katabasis is, in terms of theme, closer to Lucianic tradition than many of the surviving 12th-century poems. Therefore, we should be more cautious when we pronounce that the 12th-century satirical writings share much with Lucian. Although Prodromos' five surviving prose satires are much indebted to Lucian, his two verse satires may contain some imagery and motifs from his works (mostly references to Lucianic heroes), but their essence is also very close to the mock epigram.

Though the 12th century is the "golden age" of Lucianic satire, the Hellenistic mock epigrams seem to have also been read and imitated within the literary circle of Theodore Prodromos and Niketas Eugenianos. Moreover, we should stress that the appropriation of the mock epigram is adjusted to the needs of these two 12th-century poets, while the technique of imitation differs from author to author. Niketas Eugenianos' technique is simple and holds tighly to its model in terms of length, genre, and content. On the other hand, Prodromos' art of appropriation seems to be much more complex with a more ambitious agenda behind it. It would not do justice to the two poems to say that Prodromos simply position himself within the genre of mocking epigram (as known from the eleventh book of the Greek Anthology). First of all, although he imitates short satirical epigrams (most of them range between two and six verses), he ends up writing two lengthy mocking poems of 102 lines. How shall we understand this deviation from its model? It is true that both the ancient mock epigrams and Prodromos' poems are humorous and full of jokes, but I think that the tone in Prodromos' poems is a lot harsher. Marciniak is completely right in saying that Prodromos fused satire with an invective tone to attack stereotypical characters. ${ }^{48}$ It is likely that Prodromos was trying to produce something new in the long tradition of mock epigram by expanding its length, borrowing imageries from other satirical traditions (be they Lucianic or Aristophanic), and strengthening the element of abusiveness. In other words, he transforms the hypotext (the short mock epigram) into an extensive poem, an "abusive satire" or "satirical invective" that combines satire with psogos. In doing so, he strives to surpass his model through a multigeneric bricolage that touches upon various traditions. This would not be surprising if we think of the literary experiments that we come across in many of his other works. ${ }^{49}$

48 Marciniak, "Satire and Invective," 359-6o.

49 See, for instance, Panagiotis A. Agapitos, "New Genres in the Twelfth Century: The Schedourgia of Theodore Prodromos," Medioevo Greco 15 (2015): 1-41; Zagklas, "Prose and Verse," 229-48. 
Moreover, the element of ridicule becomes even more significant for these long poems, if we remember Marc Lauxtermann's words: "it is far easier to praise than to ridicule at length." 50 At a second level, then, it could be argued that Prodromos' lengthy mocking epigram is an attempt to show off his literary skills, which is an important thing if we think of the competitive literary and sociocultural context of this period.

The modification of the ancient mock epigram for the sake of the 12thcentury needs is not limited to the construction of a slightly different generic anatomy and the significant expansion of its lentgh, but it also extends to its metrical form. Both Eugenianos and Prodromos transform dactylic satirical epigrams into iambic ones. This is so because of the iambikè idea, which stands for the use of iamb as the most appropriate meter of verse satires throughout the entire Byzantine period. ${ }^{51}$ In addition to Eugenianos and Prodromos, another good 12th-century example is the anonymous satirical poem that recounts the funny story of a hungry man accused by his neighbor of stealing money from the 14th-century manuscript Vaticanus gr. 743, which was briefly mentioned above. ${ }^{2}$ The poem does not have a typical heading that provides a preview of its content; 53 instead, it is simply entitled " $\alpha \mu \beta \circ$, which points to the generic identity of the text: it is a satire that criticizes the practice of making accusations on dubious grounds.

\section{Abusive Attacks in Intellectual Circles: the Cases of Theodore Prodromos and John Tzetzes}

Keeping in mind that 12th-century satirical poetry is not as much Lucianic as the contemporary prose satires, let us now have a look at one context that created appropriate conditions for the production of satires and invectives: the intellectual circles of the mid-12th century. As noted above, the Prodromean poems Against a Lustful Old Woman and Against a Man with a Long Beard are directed against certain types of persons and are imbued with a strong invective tone. Since Prodromos' two poems consist of 102 verses and quite often survive together in their manuscript tradition, ${ }^{54}$ it is very tempting to argue that they were originally meant to be used together. In view of the absence

\footnotetext{
50 Lauxtermann, Byzantine Poetry, vol. 2, 120.

$5^{1} \quad$ For literature on this issue, see n. 3 .

52 Zagklas, "Seven Anonymous Poems in Vaticanus gr. 743," 895-918.

53 For the practice of labeling Byzantine poetry, see Andreas Rhoby, "Labeling Poetry in the Middle and Late Byzantine Period," Byzantion 85 (2015): 259-83.

54 See Theodore Prodromos, Satires, XLIX-L.
} 
of any tangible evidence and a certain addressee, ${ }^{55}$ it is not, however, easy to determine the exact function of these two works. Were they used together as exercises in a school setting or delivered in a literary theatron? Did they circulate in the form of pamphlets in Constantinople to ridicule certain types of people? These are difficult questions and it is not easy to give a definite answer.

But while the first poem is a vitriolic attack against the inappropriate erotic behavior of an old woman (and hence, it is more difficult to specify the context(s) of use), the latter ridicules an old man for considering himself the ultimate source of knowledge due to his long and scruffy-looking beard. As other scholars, ${ }^{56}$ I tend to read it as an attack against contemporary intellectuals and teachers. Constantinople hosted a high number of grammatikoi, often making the intellectual competition between them extremely polemic; 57 and we know that occasional writings for the court did not help Prodromos to have a sufficient income, and for this reason he was very much dependent on his profession as grammatikos. ${ }^{58}$ Consequently, he had to display his intellectualism and wide knowledge of Greek logoi on regular occasions-if necessary even to outshine other ambitious rhetors who could question his intellectual credentials. In fact, this would not have been the first time to do so. His prose satires The Ignorant, or the Grammarian in his Own Eyes and the Plato-lover, or Leatherworker are directed against intellectual frauds, ${ }^{59}$ while many of his poems are filled with complaints and subtle attacks against other unskillful rhetors. ${ }^{60}$

Given that the poem Against a Man with a Long Beard was indeed written to deride some contemporary rival teachers and intellectuals, it is worth

55 Of course, Thoukritos is not he addressee of the second poem; see Kucharski and Marciniak, "Beard and Its Philosopher," 48.

$5^{6}$ Kucharski and Marciniak, "Beard and Its Philosopher," pp. 53-54; see also Przemysław Marciniak, "Of False Philosophers and Inept Teachers: Theodore Prodromos' Satirical Writings (with a translation of the poem Against the old man with a long beard)", Byzantina Symmeikta 30 (2020): 131-48.

57 Just like in the 11h century; see Bernard, Poetry, pp. 269-72; for the 12th century, see Marina Bazzani, "The Historical Poems of Theodore Prodromos, the Epic-Homeric Revival and the Crisis of Intellectuals in Twelfth Century," Byzantinoslavica 65 (2007): 211-28.

$5^{8}$ Theodore Prodromos, Poems, ed. Nikos Zagklas, Theodore Prodromos: The Neglected Poems and Epigrams (Edition, Translation, and Commentary), PhD diss. (Vienna, 2014) , 58-72.

59 On these two works, see Dunja Milenkovic, "Knowledge and Abuse. Two Satires by Theodore Prodromos," master's thesis (CEU Budapest, 2017), 16-32. It is very interesting that Prodromos wrote satires against ignorant intellectuals both in verse and prose. The production of prose and verse works with a similar content is a common practice within his corpus (Zagklas, "Prose and Verse," 229-48).

6o Two good examples are his poems Verses of Lamentation on the Devaluation of Learning, vv. 19-28 (no. 142) and Verses of Complaint against the Providence, 103-12; for the texts and their analysis, see Zagklas, “Theodore Prodromos," 288-325. 
discussing the way Prodromos constructs his attack. Unlike other Byzantine poems, the title does not include any reference to a certain individual. It is very likely that the poem was never directed against a single individual, but rather a stereotypical type of intellectual. Although it cannot be proven, I suspect that this was the original idea of Prodromos when he presented his poem in a theatron or distributed it among his friends, as it could have been read both as an attack on this type of intellectual as well as certain rivals of Prodromos from the Constantinopolitan learned circles. ${ }^{61}$ Either way, the rebuke would have been very efficient, albeit not in an established manner. For him it was important to camouflage his attack as well as to demonstrate his vast knowledge of ancient texts. At this point we should also remember that Prodromos attempts to establish a link to mocking epigrams directed against fake intellectuals from the Greek Anthology. It is very likely that both his fellow and rival grammarians would have been able to recognize that Prodromos' attack against other intellectuals relies on a long satiric tradition, which is coupled with elements of psogos. In addition to an abusive attack, he strives to deride his rival teacher(s) through a parade of allusions to ancient texts and the use of an ancient model, which facilitate his being promoted to a more skilled intellectual than his rival(s). ${ }^{62}$

Even when he was accused by a certain Barys of showing too much interest in the classics and favoring heretical views, Prodromos noted at the very outset of his refutation: "Shall I keep my own oath not to write even a letter of invective (psogos) or should I break the oath with a poem which keeps the oath and publicly scorn his malicious nature?"63 As a matter of fact, Prodromos does both things in the remainder of the work. In order to refute the accusation of his opponent, he produced quite a long piece-it exceeds 300 dodecasyllabic verses-in which he combined features and modes from various literary genres. It is a multigeneric refutation that fuses apologia together with selfencomium and makes even use of an alphabetical acrostic in honor of the Holy Trinity. ${ }^{64}$ What is more, $p$ sogos has been embedded within the narrative of the poem: in particular, verses $204-48$ consitute a parade of tirades and

61 For instance, it resembles the poem no. 62 by Michael Psellos, in which his intellectual opponents are likened to scabies; for the authorship and some remarks of this poem, see Lauxtermann, "Texts and Contexts," in A Companion to Byzantine Poetry, 31-33.

62 As has been pointed, a similar technique can be outlined in the two prose satires (Milenkovic, "Knowledge and Abuse").

63 Theodore Prodromos, Historical Poems, no. 59, vv. 5-8; trans. in Marciniak, "Satire and Invective," 354 .

64 For the use of this acrostic and its connection to Gregory of Nazianzus, see Nikos Zagklas, "Theodore Prodromos and the Use of the Poetic Work of Gregory of Nazianzus: Appropriation in the Service of Self-Representation," Byzantine and Modern Greek Studies, $40(2016): 237-38$. 
vituperations against Barys. ${ }^{65}$ In contrast with the poem Against a Man with a Long Beard, this text is not related to an intellectual competition per se. It is rather Prodromos' orthodox beliefs that were put in question. Although the social circumstances of the genesis and function of these two texts are not exactly the same, their technique displays certain similarities. Both works share features with several genres (including satire and invective), and in both Prodromos comes out as a matchless intellectual with a wide literary knowledge. In the poem Against a Man with a Long Beard, this is proved by the familiarity and use of the Hellenistic mock epigram, while in the other poem by talking about his education and literary skills. ${ }^{66}$

Unlike Prodromos, whose works - though verbally abusive-are a mixture of satire, psogos, and occasionally other literary genres, not giving much evidence for the identity of the rival, other 12th-century grammarians act slightly differently. I will only discuss the example of Prodromos' contemporary John Tzetzes. Needless to say, Tzetzes is an excessive case of intellectual rivalry in Byzantium who did not confine his attacks against contemporary teachers. ${ }^{67}$ For example, in an iambic poem he derides a woman who aspires to write schede, ${ }^{68}$ while in some of his writings he even attacks ancient authors. ${ }^{69}$ As

65 For example, he is even called son of a pig (vv. 235-41).

66 Theodore Prodromos, Historical Poems, no. 59, 168-203.

67 Many of them are to be found in his Chiliades; e.g. John Tzetzes, Chiliades, ed. Pietro Luigi M. Leone, Ioannis Tzetzae Historiae, 2nd ed. (Galatina, 2007), book XI, 212-24, in which Tzetzes attacks another Constantinopolitan rhetor. For this passage, see Panagiotis A. Agapitos, "Grammar, Genre and Patronage in the Twelfth Century: A Scientific Paradigm and Its Implications," Jahrbuch der Österreichischen Byzantinistik 64 (2014): 13; Agapitos, "John Tzetzes and the Blemish Examiner: A Byzantine Teacher on Schedography, Everyday Language and Writerly Disposition," Medioevo Greco 17 (2017): 22-27.

68 John Tzetzes, Poem, ed. Silvio Giuseppe Mercati, "Giambi di Giovanni Tzetze contro una donna schedografa," in Collectanea Byzantina, ed. Augusta Acconcia Longo, vol. 1 (Bari, 1970), p. 556; for some remarks and an English translation of the poem, see Agapitos, "John Tzetzes," 15.

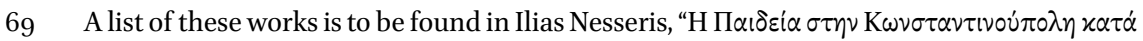
$\tau o v 120 \alpha \iota \dot{\omega} v \alpha, "$ PhD diss. (Ioannina, 2014), p. 525. Of special interest is an epigram that lambasts Lycophron for his lexical options. In the manuscript tradition, the epigram is attributed either to John Tzetzes or his brother Isaac Tzetzes. I tend to believe that it was a work of the former. For the text, see Andreas Rhoby, Ausgewählte byzantinische Epigramme in illuminierten Handschriften: Verse und ihre, inschriftliche' Verwendung in Codices des 9. bis 15. Jahrhunderts, vol. 4 (Vienna, 2018), 115-18; Claudio De Stefani and Enrico Magnelli, "Lycophron in Byzantine Poetry (and Prose)," in Lycophron: éclats d'obscurité. Actes du colloque international de Lyon et Saint-Étienne 18-20 janvier 2007, ed. C. Cusset and E. Prioux (Saint-Étienne, 2009), 593-620. 
one of the most agonistic authors he composes abusive poems that are very close to psogos. A completely neglected poem demonstrates this in an explicit manner. ${ }^{70}$ The title of the poem is quite long and affords some insight into the identity of the addressees of the attack as well as the motivations behind Tzetzes' attack.

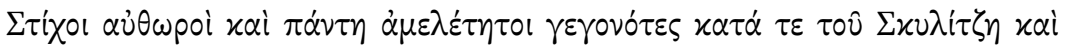

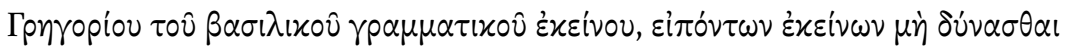

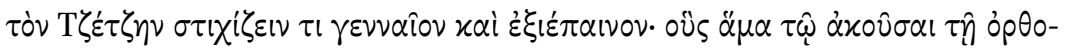

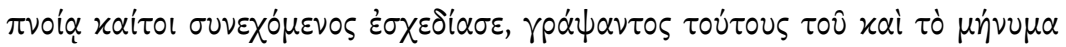

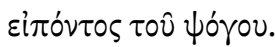

Verses composed on-the-spot and completely unprepared ${ }^{71}$ against Skylitzes and that imperial grammarian Gregory, when they said that Tzetzes is not able to versify anything noble and praiseworthy; upon hearing these things, he improvised them though distressed by his shortness of breath, ${ }^{72}$ when he wrote them down and delivered the message of the psogos. ${ }^{73}$

The poem is directed against Skylitzes, who most likely is to be identified as George Skylitzes, a very successful official and author of the dedicatory poem for Andronikos Kamateros' Sacred Arsenal commissioned by Manuel Komnenos and probably another ten poems preserved in Marcianus gr. $524,{ }^{74}$

70 John Tzetzes, Poem against George Skylitzes and Gregory the Imperial Secretary, ed. Sophronios Pétridès, "Vers inédits de Jean Tzetzes," Byzantinische Zeitschrift 12 (1903): 56870. The poem has only been discussed in Agapitos, "John Tzetzes," 23 and Paul Magdalino, "Cultural Change? The Context of Byzantine Poetry from Geometres to Prodromos," in Poetry and Its Contexts in Eleventh-Century Byzantium, ed. Floris Bernard and Kristoffel Demoen (Farnham/Burlington, 2012), 31.

71 The word $\alpha \mu \varepsilon \lambda \varepsilon \dot{\tau} \eta \eta \leftarrow \varsigma$ can also be translated as "unstudied"; see Agapitos, "John Tzetzes," 37 .

72 Tzetzes refers to this disease in his Chiliades too; see John Tzetzes, Chiliades, book VI, 37, vv. 71-73.

73 For a slightly alternative translation of the title, see Magdalino, "Cultural Change," 31.

74 Andreas Rhoby, "Zur Identifizierung von bekannten Autoren im Codex Marcianus Graecus 524," Medioevo Greco 10 (2010): 167-204. Lambros nos. 81, 88, 91, 93, 94, 97, 230, 249, 336, 347. For Skylitzes, see Alessandra Bucossi, "George Skylitzes' Dedicatory Verses for the Sacred Arsenal by Andronikos Kamateros and the Codex Marcianus Graecus 524," 37. He was also the author of liturgical poetry (Theodora Antonopoulou, "George Skylitzes' Office on the Translation of the Holy Stone: A Study and Critical Edition," in The Pantokrator Monastery in Constantinople, ed. Sofia Kotzabassi (Boston, MA, 2013), 109-41). 
as well as a certain Gregory, who was imperial secretary at the time. ${ }^{75}$ Tzetzes was accused by them of being incapable of composing good poetry. For this reason, he claims that he composed on the spot an invective as a kind of counterattack. ${ }^{76}$ It is very interesting that the title points to the generic identity of the poem: it is a భóros. The poem basically builds upon a human-animal synkrisis. Skylitzes and Gregory are compared with goats. At the opening of the poem, Tzetzes says that no milk can be extracted from the goats and the only thing they are able to do is to attack with their horns (as goats butt with their heads after a good meal, so do George Skylitzes and Gregory), clearly insinuating that the two rival authors are not capable of writing anything worthy and for this reason attack him. Then, the attack becomes even more abusive and coarse. ${ }^{77}$

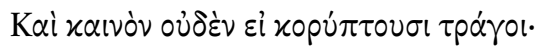

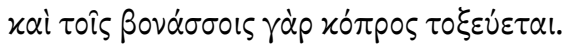

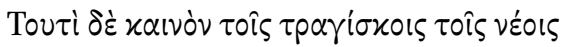

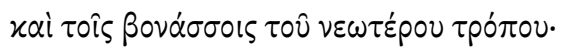

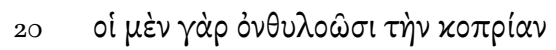

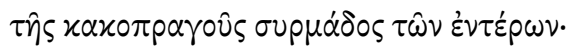

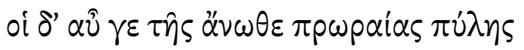

$\alpha \nu 0 \nu \theta v \lambda \circ v \hat{\sigma} \sigma \nu \dot{\alpha} \pi \rho \varepsilon \pi \hat{\eta} \delta v \sigma o \delta \mu i \alpha \nu$,

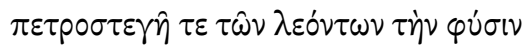

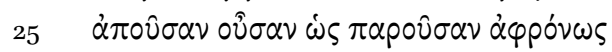

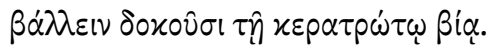

75 The only Gregory that was imperial secretary in the second half of the 12th century is Gregory Antiochos. However, we do not know if he wrote any poetry. On this possible

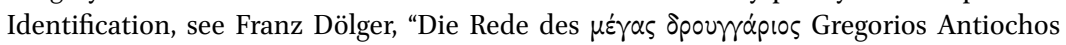
auf den Sebastokrator Konstantinos Angelos," Byzantinische Zeitschrift 40 (1940): 36o n. 2. Agapitos has noted that the imperial secretary Gregory cannot be identified with an unnamed rhetor attacked in other tzetzian writings ("John Tzetzes," p. 23, n. 121).

$7_{6}$ Moreover, in the title of his Theogony Tzetzes notes that he wrote it ex tempore; see Agapitos, "John Tzetzes," 37. There is a good deal of Byzantine poems that bears witness to this practice. For example, Leo toy Megistou was commissioned by the Megas Hetairiarches Georgios Palaiologos to write a poem on the spot (Odysseus Lampsides, "Die Entblößung der Muse Kalliope in einem byzantinischen Epigramm," Jahrbuch der Österreichischen Byzantinistik 47 (1997): 107-10). However, the practice of writing instantaneous poetry should be further examined.

77 John Tzetzes, Poem against George Skylitzes and Gregory the Imperial Secretary, pp. 5697o, vv. $16-26$. 
And there is nothing novel if goats butt with their heads; and indeed the excrements of the buffaloes hit like an arrow. But this is novel as regards the young he-goats and the more novel manner of buffaloes: for the buffaloes produce their dung from the wicked pile of their intestines; the goats produce an unpleasant smell from the upper front gate (i.e. their mouth), and foolishly thinking they can hit with the force of their horns the steadfast nature of lions, as if it were present, though it is not.

The imagery used here aims to contribute to Tzetzes' intellectual superiority over his rivals. Whereas his opponents are stinky goats, he is, of course, a mighty lion, and for this reason they do not dare to openly challenge him. ${ }^{78}$ Unlike his mediocre opponents, he is a successful attacker. Thus, it is better not to challenge him, because if they do, the consequences will be dreadful for them: ${ }^{79}$

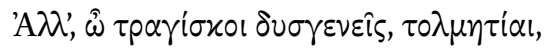

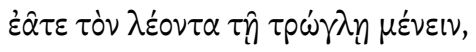

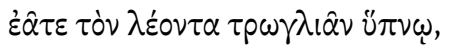 \\ $\mu \eta \dot{\tau} \tau \dot{\alpha} \varsigma \tau p \alpha \gamma \alpha \hat{\varsigma}, \tau \dot{\alpha} \varsigma \sigma \dot{\alpha} p x \alpha \varsigma, \dot{o} \sigma \tau \hat{\alpha}, \tau \dot{\alpha} x \dot{\varepsilon} \rho \alpha$

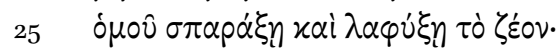

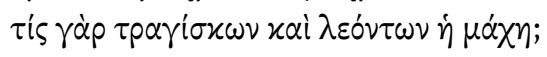

But, you low-minded and bold goats, let the lion stay in his lair, let the lion sleep in his lair, otherwise he will tear apart the goatskins, the fleshes, the bones, the horns altogether and will gulp down the inner parts; what is the purpose of a battle between goats and lions?

The texts by Prodromos and Tzetzes have some similarities; for instance, in terms of animal imagery, since in both poems the rival intellectuals are compared to stinking goats with horns. ${ }^{80}$ However, Tzetzes' text does not seem to build upon a certain literary hypotext nor is it a fusion of satire with invective. It leans more toward $p$ sogos, since the poet hurls abuse against his opponents

78 The animal imagery plays a very important role in Tzetzes' attacks; see Agapitos, "John Tzetzes," 20.

79 John Tzetzes, Poem against George Skylitzes and Gregory the Imperial Secretary, p. 570, vv. $27-3^{2}$.

8o The stinky smell of goats is a topos in literary texts since the time of antiquity; see, for instance, Aristophanes, Plutus, 294. Moreover, in many of his work, Tzetzes calls his opponents 'sons of he-goats' (that is, bastards); see Marc D. Lauxtermann, "Buffaloes and Bastards: Tzetzes on Metre" (forthcoming). 
by comparing them to stinky goats. In other words, whereas Prodromos forms a subversive piece, Tzetzes' text is clearly a frontal attack. ${ }^{81}$

Furthermore, in contrast with Prodromos' poem, which does not teem with specific details about its use, the exact context of Tzetzes' poem can further be reconstructed with the help of one of his letters: that is, letter 89, which is directed to the sons of Andronikos Kamateros. ${ }^{82}$ In this letter Tzetzes apologizes for his harsh critique of some hexametric verses by Gregory, who must be the same person as the imperial secretary Gregory, whom Tzetzes attacked in the poem under discussion. Gregory, in turn, ridiculed Tzetzes for his composition of iambic verses. Tzetzes claims that he would like to have the opportunity to present his iambic verses in a koinos syllogos (most probably, a literary theatron) in order to refute his rival's claims. ${ }^{83}$ It is possible that Tzetzes' poem was most probably part of a "poetic dispute," including various stages and polemical writings. Indeed, in the 13th-century Viennese manuscript philologicus gr. $321\left(\right.$ fol. $43^{\mathrm{r}}$ )—right after the poem against Skylitzes and Gregory—survives yet another poem by Tzetzes against them, which remains unedited. ${ }^{84}$

In the beginning this "poetic dispute" might have been a private one, but at sometime it moved to the public sphere, with group of works filled with reproaches and rebukes exchanged in succession between the authors in the context of a literary theatron. This is a well-attested practice in Byzantium going as far back as the 1oth century. The most well-known disputes are that of Constantine the Rhodian and Theodore the Paphlagonian in the early 1oth century, ${ }^{85}$ John Geometres and a certain Stylianos in the late 1oth century, ${ }^{86}$ and Psellos and Sabbaites in the 11th century. ${ }^{87}$

Another difference is that Prodromos' accusations for the intellectual ignorance of his rival(s) remains, to a certain extent, unspecified. On the other hand, thanks to the detailed title of the poem and his letter 89, we can determine that the dispute between Tzetzes, Skylitzes, and Gregory is associated with the capability to write good poetry. Tzetzes was the one who initiated

81 It resembles works by John Mauropous and Christopher Mitylenaios; see Bernard, Poetry, 266-8o.

82 John Tzetzes, Letters, ed. Pietro Luigi M. Leone, Ioannis Tzetzae epistulae (Leipzig, 1972), no. 89 .

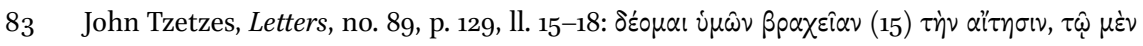

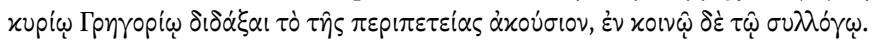

84 Pétridès was unaware of this manuscript because he edited the poem solely on the basis of Parisinus gr. 2925. Panagiotis Agapitos has kindly informed me that he is working on a new edition of this poem.

85 Lauxteramann, Byzantine Poetry, vol. 2, 134-35.

86 Van Opstall, "An Invective Dialogue" and Lauxteramann, Byzantine Poetry, vol. 2, 135-36.

87 Bernard, Poetry, 280-9o. 
the above-mentioned dispute by criticizing the hexametric verses of Gregory. Then, Gregory and George Skylitzes inveighed against Tzetzes' iambic verses. It is quite tempting to think that this accusation is partly linked with Tzetzes' technical iambs, which, in contrast with the regular dodecasyllables, contain resolutions. ${ }^{88}$ Although in the letter he says that his opponents criticize the style of his iambic verse, I would argue that the metric experiments of Tzetzes, which ran counter to the long tradition of the Byzantine dodecasyllable, was one of the reasons that Skylitzes and Gregory questioned his poetic skills. ${ }^{89}$ Be that as it may, this was not the only time that Tzetzes was involved in such a poetic dispute or that he targeted another contemporary author. In some of his writings he accuses both older and modern philologists for the wrong use of dichrona.$^{90}$ Moreover, there is an extraordinary poem of only two verses linked with an attack on metric grounds which is ascribed to him in a number of manuscripts: ${ }^{91}$

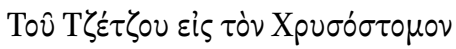

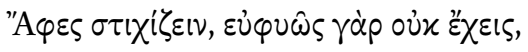

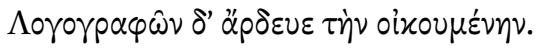

Stop to versify, for you are not very skilful, but irrigate the world by writing prose works.

Here, Tzetzes criticizes the incapability of the addressee to compose poetry. Although Tzetzes attacked ancient authors and philologists in some of his writings, this does not seem to be such a work. It is not a rebuke against John

88 For his technical iambs, see Georg Hart, "De Tzetzarum nomine vitis scriptis," Jahrbücher für classische Philologie: Supplementband 12 (1881): 66-75; Friedrich Kuhn, Symbolae

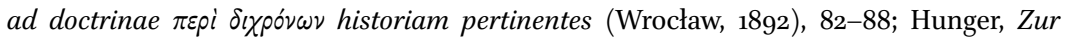
Interpretation polemischer Stellen im Aristophanes-Kommentar des Johannes Tzetzes, 59-64.

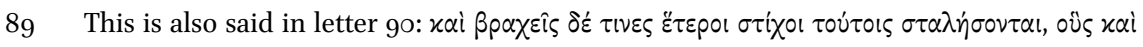
$\beta \alpha \sigma \alpha \nu i \sigma \alpha \dot{\tau} \omega \sigma \alpha \nu \tau \varepsilon \chi \nu i x \omega \hat{\varsigma}$.

9o See, for instance, the poem that is part of his commentary on Plutus; text in John Tzetzes, Commentaries on Aristophanes I, ed. Lydia Massa Positano, Jo. Tzetzae Commentarii in Aristophanem, Fasc. I: Prolegomena et commentarius in Plutum (Groningen, 1960), 41-46; on this issue, see Lauxtermann, "Buffaloes and Bastards: Tzetzes on Metre" (forthcoming).

91 Vaticanus gr. 1126, Bodl. Roe 1, and Vatic. Barb. Gr. 74. For the text, see Manuel Philes, Poems, Emmanuel Miller, Manuelis Philae Carmina ex codicibus Escurialensibus, Florentinis, Parisinis \& Vaticanis, vol. 2 (Paris, 1857), p. 269; Henry O. Coxe, Bodleian Library Quarto Catalogues, I: Greek Manuscripts, Reprinted with Corrections from the Edition of 1853, vol. 1 (Oxford, 1969), p. 478; Valentino Capocci, Codices Barberiniani Graeci. Tomus I: Codices 1-163, In Bibliotheca Vaticana, vol. 1 (Rome, 1958), 86. 
Chrysostom, but most probably a contemporary author of Tzetzes-a pseudoChrysostom. There are two short poems that survive under the name of John Chrysostom in a number of manuscripts: the first one is an epigram on the Eucharist, ${ }^{92}$ the latter a short paraenetic poem of 14 verses. ${ }^{93}$ Given that the manuscripts of the two poems date between the 13th and 16th centuries, it is likely that they are works by the 12th-century author that Tzetzes attacks. Moreover, the latter poem is of special interest, since it teems with metrical errors. It is worth citing a couple of verses to see the blunt metrical errors the anonymous author commited and which brought about Tzetztes' attack.

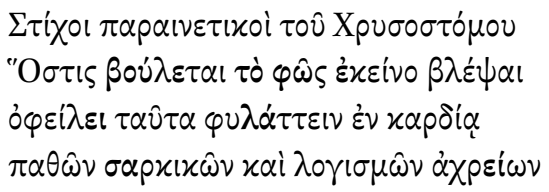

Most probably, the author of this poem is the one at which Tzetzes directed his attack. According to the poem, the anonymous addressee of the poem can write excellent works in prose, but his skills of writing prosodically correct verses is put in question. If we compare this poem with the one against George Skylitzes and the imperial secretary Gregory, the former is much less vitriolic and without abusive imagery demonstrating that the art of debunking a contemporary intellectual differentiates even within the corpus of one author.

To conclude, it is certain that the 12th century signified a shift in Byzantine satire with the writing of satires in Lucianic style, but this is mostly the case for prose works. Satirical poetry was intermingled with some Lucianic imagery, but it continued to owe much to the Hellenistic mocking epigram, since Komnenian authors found many paradigms for their attacks in the eleventh book of the Greek Anthology. The satirical discourse turns out to be quite diverse in the second quarter of the 12th century with the help of the ancients: both Theodore Prodromos and Niketas Eugenianos wrote prose satires in Lucianic manner, ${ }^{94}$ but also modeled on scoptic epigram for the composition of satirical writings. Moreover, the former went a step further by expanding the length of the mocking epigram and embellishing its tropes with an even more abusive tone.

92 The poem is only partly edited, see Pseudo- Chrysostom, Poem on the Eucharist, ed. Spyridon Lambros, Neos Ellenomnemon (1925): 61.

93 Jean Baptiste Pitra, Juris ecclesiastici Graecorum historia et monumenta, vol. 2 (Rome, 1864-68), p. 170.

94 The work Anacharsis, a satire in Lucianic manner, is ascribed to Niketas Eugenianos; for a discussion of this work, see Chapter 11 in this volume. 
Although there are satires on varying themes, the lampoon of intellectual opponents seems to have been one of the main extratextual purposes of 12th-century satiric poetry (as was the case in other periods of Byzantium). It is difficult to say whether the Komnenian satirical discourse is more or less offensive than that of other periods, but we can surely see some differences in the way some contemporary authors construct their attacks. Whereas Prodromos attacks are often subtly built upon the appropriation of the Greek anthology, Tzetzes does not hesitate to use fierce psogos in sensu stricto. These works are not only different types of Komnenian satirical discourse, but they also mirror the different way these two authors acted within the mid-12th-century intellectual setting. Prodromos seems to be more cautious and subversive. As far as we know he never openly attacked powerful individuals, being possibly aware of the complexity of the 12th-century social reality and the fact that he was making part of his living out of commissions. On the other hand, these social and intellectual conventions did not stop Tzetzes from hurling abuse even against high-ranking officials, even though they could influence his number of commissions and eventually hinder his social aspirations. ${ }^{95}$

95 This chapter was written within the frame of the project "Byzantine Poetry in the 'Long' Twelfth Century (1081-1204): Texts and Contexts," funded by the Austrian Science Fund (FWF P 28959-G25). Earlier drafts of the chapter were presented to conferences or seminars in Athens, Nicosia, and Oxford. I would like to thank all the participants for their helpful feedback. My thanks also to the editors and Andreas Rhoby for their remarks and corrections. 